\title{
Discovery of anti-SARS-CoV-2 agents from commercially available flavor via docking screening
}

Jiao-Jiao Zhang ${ }^{1, \dagger}$, Xin Shen ${ }^{2, \dagger}$, Yong-Ming Yan $^{1}$, Yan Wang ${ }^{2, *}$, Yong-Xian Cheng ${ }^{1, *}$

${ }^{1}$ School of Pharmaceutical Sciences, Shenzhen University Health Science Center, Shenzhen 518060, P.R. China

${ }^{2}$ Center for Translation Medicine Research and Development, Shenzhen Institute of Advanced Technology, Chinese Academy of Sciences, Shenzhen 518055, P.R. China

* To whom correspondence should be addressed: Tel: 86755-2690 2073; E-mail: yxcheng@szu.edu.cn (Y.-X. C.); 86755-2641 7985; E-mail: yan.wang@siat.ac.cn (Y. W.)

$\dagger$ These authors contributed equally to this paper.

Running Title: Flavor ingredients against 2019-nCoV by docking screening

Keywords: 2019-nCoV, novel coronavirus pneumonia, docking, ACE2, viral main protease, flavor 


\section{Abstract}

Flavor and spice is largely consumed in food, cosmetics, and pharmaceutical industries. A novel coronavirus, recently named the Severe Acute Respiratory Syndrome Coronavirus 2 (SARS-CoV-2), was first identified in humans in Wuhan China in 2019. This study is to examine whether the flavor components can prevent human from SARS-CoV-2 infection. Given that the druggable antiviral target ACE2 receptor and viral main protease were reported, 169 compounds were screened against these two targets by using autodock vina. According to our docking screening, 10 antiviral components, including glycyrrhizic acid, theaflavin 3,3'-digallate, agnuside, fenflumizole, angelicide, sageone, oleanic acid, benzyl (3-fluoro-4-morpholine-4-yl phenyl) carbamate, glycerol ester of rosin, and endere S can directly bind to both host cell target ACE2 receptor and viral target main protease, indicating their potential for SARS-CoV-2 treatment. 


\section{Introduction}

The Severe Acute Respiratory Syndrome Coronavirus 2 (SARS-CoV-2), previously named as 2019 novel coronavirus (2019-nCoV), is a positive-sense, single-strand RNA coronavirus. SARS-CoV-2 caused an ongoing outbreak of coronavirus disease 2019 (COVID-19), which started in December 2019 (1). Given that the emergence of SARS-CoV-2, drug repurposing study was immediately conducted by both virtual screening and cell-based screening, which provided several promising antiviral agents from approved drugs (2). Flavor and spice has been widely used in China and India since ancient time, some spice such as ginger and pepper is used to fight against dampness evil in the body according to the philosophy of traditional Chinese medicine, however, whether these components do prevent from virus infection is still questionable. Here we tried to use molecular docking screening to identify potential anti-SARS-CoV-2 agents from flavor ingredients.

Not surprisingly, spike protein of SARS-CoV-2 can directly bind to angiotensin converting enzyme 2 (ACE2) receptor of host cells (3). Inhibition of ACE2 catalytic pocket by small molecules could change the conformation of ACE2, indicating that ACE2 inhibitor could block SARS-CoV-2 entry $(4,5)$. Therefore we selected ACE2 receptor as a protein model to quickly identify entry inhibitors of SARS-CoV-2. 
Besides the blockade of viral entry, the inhibition of viral replication is another good strategy for antiviral drug discovery and development (6). Given that SARS-CoV-2 is a (+)SS RNA virus, its main protease could cut two replicase polyproteins, which is required to mediate viral replication and transcription. In this way, the inhibitor of main protease might block virus replication. The crystal structure of SARS-CoV-2 main protease (PDB: 6LU7) was reported (7). We consequently docked flavor components to main protease to look for antiviral replication agents.

\section{Materials and Methods}

The three dimensional structure of ligands (aroma oil components) were generated by CORINA online service (https://www.mn-am.com/online_demos/corina demo). Then the PDB ligand was converted to PDBQT ligand using Autodock Tools. The protein model 1R4L was selected as ACE2 receptor docking model while 6LU7 was selected as $\mathrm{M}$ protease docking model. Both PDB files of protein models were fetched from Protein Data Bank. The docking screening were conducted by using AutoDock Vina v.1.0.2. The docking parameters for AutoDock Vina were kept at their default values. The grid box was $25 \AA$ by $25 \AA$ by $25 \AA$, encompassing the catalytic pocket. The binding modes were clustered through the root mean square deviation (RMSD) among the Cartesian coordinates of the ligand atoms. The docking results were ranked by the binding free energy. The binding results were graphically presented by using PyMOL1.3 (Schrödinger, LLC). 


\section{Results}

Totally we docked 169 flavor components to two drug targets. The top 10 hits are summarized in Tables 1 and 2. The top ten hits are glycyrrhizic acid, theaflavin 3,3'-digallate, agnuside, fenflumizole, angelicide, sageone, oleanic acid, benzyl (3-fluoro-4-morpholine-4-yl phenyl) carbamate, glycerol ester of rosin, and endere S. Interestingly, the majority of the components are also found in traditional Chinese medicine with the exception of fenflumizole and benzyl (3-fluoro-4-morpholine-4-yl phenyl) carbamate. As for ACE2 receptor, 11 out of 169 compounds exhibit good binding affinities $(<-9 \mathrm{kcal} / \mathrm{mol})$, they are glycyrrhizic acid, theaflavin 3,3'-digallate, agnuside, fenflumizole, angelicide, sageone, oleanic acid, benzyl (3-fluoro-4-morpholine-4-yl phenyl) carbamate, glycerol ester of rosin, endere S, and testosterone; Of which, glycyrrhizic acid and oleanic acid are triterpenoidal acids. Besides, 3 out of 169 compounds, glycyrrhizic acid, theaflavin 3,3'-digallate and agnuside, inhibit main protease with strong binding affinities $(<-9 \mathrm{kcal} / \mathrm{mol})$. Of note, the properties of glycyrrhizic acid against SARS-CoV-2 have been pointed out in our previous investigation (8). It is also interesting that theaflavin 3,3'-digallate, a phenolic compound present in ginger, was found to interact both with ACE2 receptor and $\mathrm{M}$ protease with considerable biding affinities. It is worth mentioning that the current mainstream view about SARS-CoV-2 is the observation of inflammation storm leading to the death. However, we believe that there should have typical "free 
radical storm" or severe oxidative stress during SARS-CoV-2 in view of biomedical or chemical defense. Normally, inflammation and free radical including reactive oxygen species is a powerful weapon for human body against evils. Our present finding of theaflavin 3,3'-digallate and previous results regarding to phenolics as hits (8) prompted us to consider their effects against SARS-CoV-2 might be also associated with their antioxidant potency. With this rationale, we tentatively suggest that marketed antioxidants such as edaravone and intake of ginger with high content of phenolics might be beneficial for SARS-CoV-2 patients. Unfortunately, this hypothesis and therapeutic approach has been largely ignored during SARS-CoV-2 outbreak. Last but not the least, it is not surprising that the other flavor agents are not hits with super good binding energy $(<-10 \mathrm{kcal} / \mathrm{mol})$ ( Table appendix) because their chemical structures are relative simple, so that it is difficult for them to occupy the whole catalytic pocket and provide high binding affinities.

\section{Conclusion}

Drug repurposing is a common strategy to fight novel coronavirus. However, most of drug repurposing study is about FDA approved drugs. Flavor ingredients were widely used to prevent plague in ancient China and India and are commercially available with good supply. We were curious that whether flavor ingredients can also prevent SARS-CoV-2 at this time. According to docking screening, we found that flavor ingredients including glycyrrhizic acid, theaflavin 3,3'-digallate, and agnuside are 
most likely to directly bind to both viral $M$ protease and ACE2 receptor, lending a hand for fighting against SARS-CoV-2.

\section{Acknowledgments}

This study was supported by the National Science Fund for Distinguished Young Scholars (81525026) and National Natural Science Foundation of China (81903875).

\section{Competing interest statement}

The authors declare no conflict of interest.

\section{References}

1. Huang CL, Wang YM, Li XW, Ren LL, Zhao JP, Hu Y, Zhang L, Fan GH, Xu, JY, Gu, XY, Cheng ZS, Yu, T, Xia JA, Wei A, Wu, WJ, Xie XL, Yin W, Li H, Liu, M, Xiao Y, Gao H,Guo L, Xie JG, Wang GF, Jiang RM, Gao ZC, Jin Q, Wang JW, Cao B. Clinical features of patients infected with 2019 novel coronavirus in Wuhan, China. Lancet, 2020; doi: 10.1016/S0140-6736(20)30183-5.

2. Wang ML, Cao RY, Zhang LK, Yang XL, Liu J. Xu MY, Shi ZL, Hu ZH, Zhong W, Xiao GF. Remdesivir and chloroquine effectively inhibit the recently emerged novel coronavirus (2019-nCoV) in vitro. Cell Res., 2020; doi: 10.1038/s41422-020-0282-0.

3. Wan YS, Shang J, Graham R, Baric RS, Li F. Receptor recognition by novel coronavirus from Wuhan: An analysis based on decade-long structural studies of 
SARS. J. Virol., 2020; doi: 10.1128/JVI.00127-20.

4. Du LY, He YX, Zhou YS, Liu SW, Zheng BJ, Jiang SB. The spike protein of SARS-CoV -a target for vaccine and therapeutic development. Nat. Rev. Microbiol., 2009; 7(3): 226-236.

5. Towler P, Staker B, Prasad SG, Menon S, Tang J, Parsons T, Ryan D, Fisher M, Williams D, Dales NA, Patane MA, Pantoliano MW. ACE2 X-ray structures reveal a large hinge-bending motion important for inhibitor binding and catalysis. J. Biol. Chem., 2004; 279(17):17996-8007.

6. Clercq ED. Strategies in the design of antiviral drugs. Nat. Rev. Drug Discov., 2002; 1: $13-25$.

7. Wit ED, van Doremalen NV, Falzarano D, Munster VJ. SARS and MERS: recent insights into emerging coronaviruses. Nat. Rev. Microbiol., 2016; 14: 523-534.

8. Yan YY, Shen X, Cao YK, Zhang JJ, Wang Y, Cheng YX. 2020, DOI: 10.20944/preprints202002.0254.v2. 
Table 1. Top 10 flavor agents docking results

\begin{tabular}{cccc}
\hline \multirow{2}{*}{ Ligand } & \multicolumn{3}{c}{ Binding Energy } \\
\cline { 2 - 4 } & 1R4L & 6LU7 & Sum \\
\hline Glycyrrhizic acid & -9.6 & -9.3 & -18.9 \\
\hline Theaflavin 3,3'-digallate & -8.3 & -10 & -18.3 \\
Agnuside & -9.6 & -8 & -17.6 \\
Fenflumizole & -9.5 & -7.7 & -17.2 \\
Angelicide & -9.7 & -7.1 & -16.8 \\
Sageone & -9 & -7.8 & -16.8 \\
Oleanic acid & -9.4 & -7.3 & -16.7 \\
Benzyl (3-fluoro-4-morpholine-4-yl phenyl) carbamate & -9.4 & -7.1 & -16.5 \\
Glycerol ester of rosin & -9.4 & -6.9 & -16.3 \\
Endere S & -9.4 & -6.8 & -16.2 \\
\hline
\end{tabular}


Table 2. Key residues for the inhibitor binding

\begin{tabular}{|c|c|c|}
\hline \multirow{2}{*}{ Ligand } & \multicolumn{2}{|c|}{ Key residues } \\
\hline & 1R4L & 6LU7 \\
\hline Glycyrrhizic acid & $\begin{array}{l}\text { Arg273, His345, } \\
\text { Ala348, Thr365, } \\
\text { Arg518 }\end{array}$ & $\begin{array}{c}\text { Phe140, Gly143, His 163, } \\
\text { Gln189 }\end{array}$ \\
\hline Theaflavin 3,3'-digallate & $\begin{array}{l}\text { Asn149, Asn154, } \\
\text { Arg273, Asn277, } \\
\text { His345, Lys363, } \\
\text { Thr365, Arg518 }\end{array}$ & $\begin{array}{c}\text { Ser46, Tyr54, Phe140, } \\
\text { Ser144, Cys145, Gly143, } \\
\text { His163, Glu166, Gln189, } \\
\text { Thr190 }\end{array}$ \\
\hline Agnuside & $\begin{array}{l}\text { His345, Thr371, } \\
\text { Glu406, Arg518 }\end{array}$ & $\begin{array}{c}\text { Thr24, Thr45, Leu141, } \\
\text { Gly143, Ser144, Cys145, } \\
\text { Glu166 }\end{array}$ \\
\hline Fenflumizole & His345 & None \\
\hline Angelicide & None & Gly143, Ser144, Cys145 \\
\hline Sageone & Arg273, His345 & Gly143, Ser144, Cys145 \\
\hline Oleanic acid & Glu406 & none \\
\hline $\begin{array}{c}\text { Benzyl } \\
\text { (3-fluoro-4-morpholine-4-y } \\
1 \text { phenyl) carbamate }\end{array}$ & $\begin{array}{l}\text { Arg273, His } 345, \\
\text { Thr445, Tyr515 }\end{array}$ & $\begin{array}{c}\text { Gly143, Ser144, Cys145, } \\
\text { His163 }\end{array}$ \\
\hline Glycerol ester of rosin & $\begin{array}{c}\operatorname{Arg} 273, \text { His } 374, \\
\text { Arg5 } 18\end{array}$ & Gly143, His163 \\
\hline Endere S & Arg273, Arg518 & Gly143, His163 \\
\hline
\end{tabular}


Appendix Table 1. Flavor agents docking results






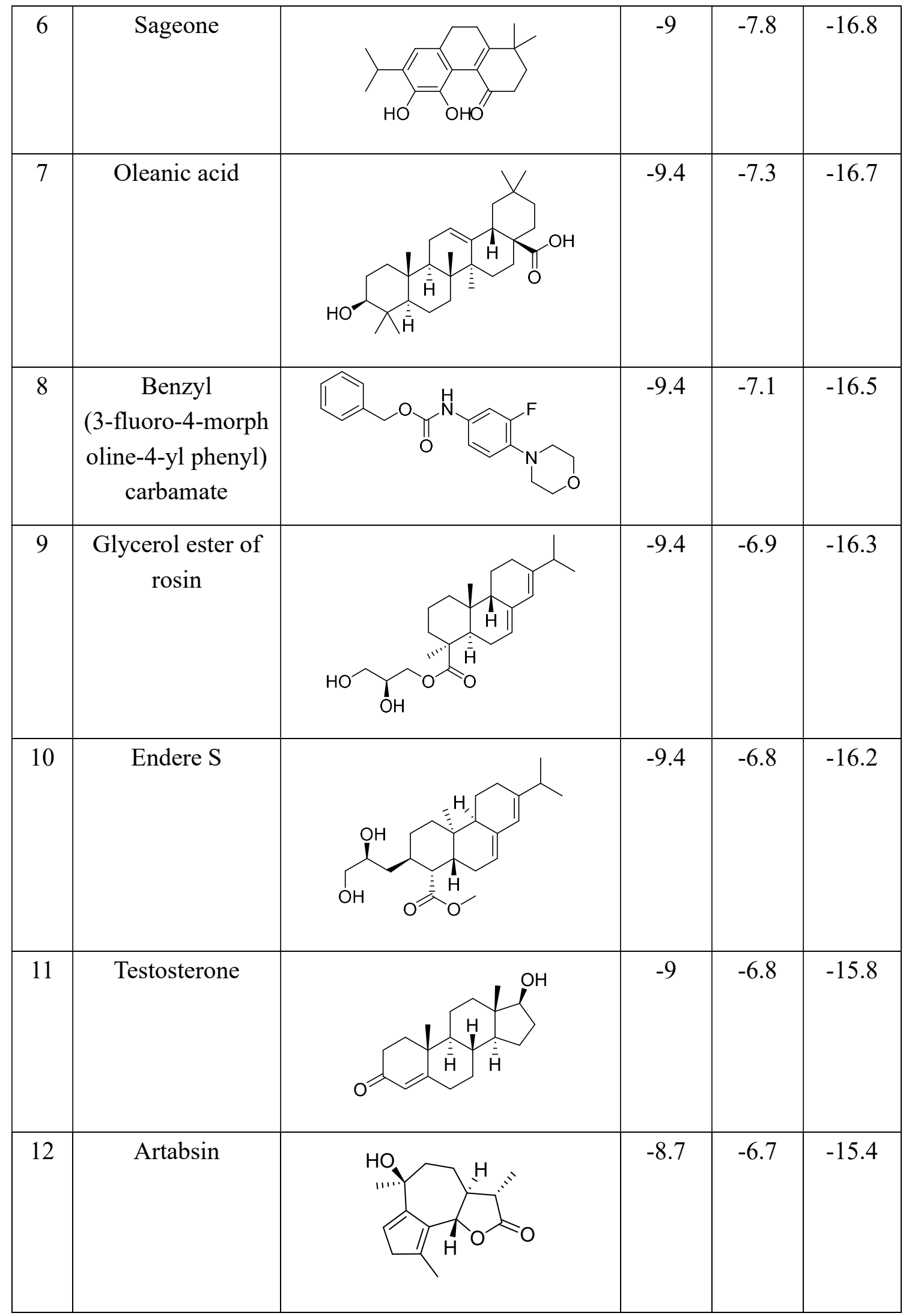




\begin{tabular}{|c|c|c|c|c|c|}
\hline 13 & Elantrine & & -8.6 & -6.8 & -15.4 \\
\hline 14 & Piperine & & -8.3 & -6.6 & -14.9 \\
\hline 15 & Nonanal & ר & -8.1 & -6.6 & -14.7 \\
\hline 16 & $\begin{array}{c}(1 R, 2 S, 5 R)-2-\text { Isop } \\
\text { ropyl- } N \text {-(4-metho } \\
\text { xyphenyl)-5-meth } \\
\text { ylcyclohexane-1-c } \\
\text { arboxamide }\end{array}$ & & -8.2 & -6.2 & -14.4 \\
\hline 17 & $\begin{array}{l}\text { 2,5-Dimethyl-4-(2 } \\
\text {-thienylaminosulp } \\
\text { honyl)furan-3-car } \\
\text { boxylic }\end{array}$ & & -7.7 & -6.6 & -14.3 \\
\hline 18 & Angelicone & & -7.9 & -6.3 & -14.2 \\
\hline 19 & Traseolide & & -7.7 & -6.3 & -14 \\
\hline 20 & Vitamin A & & -8.3 & -5.6 & -13.9 \\
\hline 21 & Curcumadione & & -7.5 & -6.1 & -13.6 \\
\hline
\end{tabular}




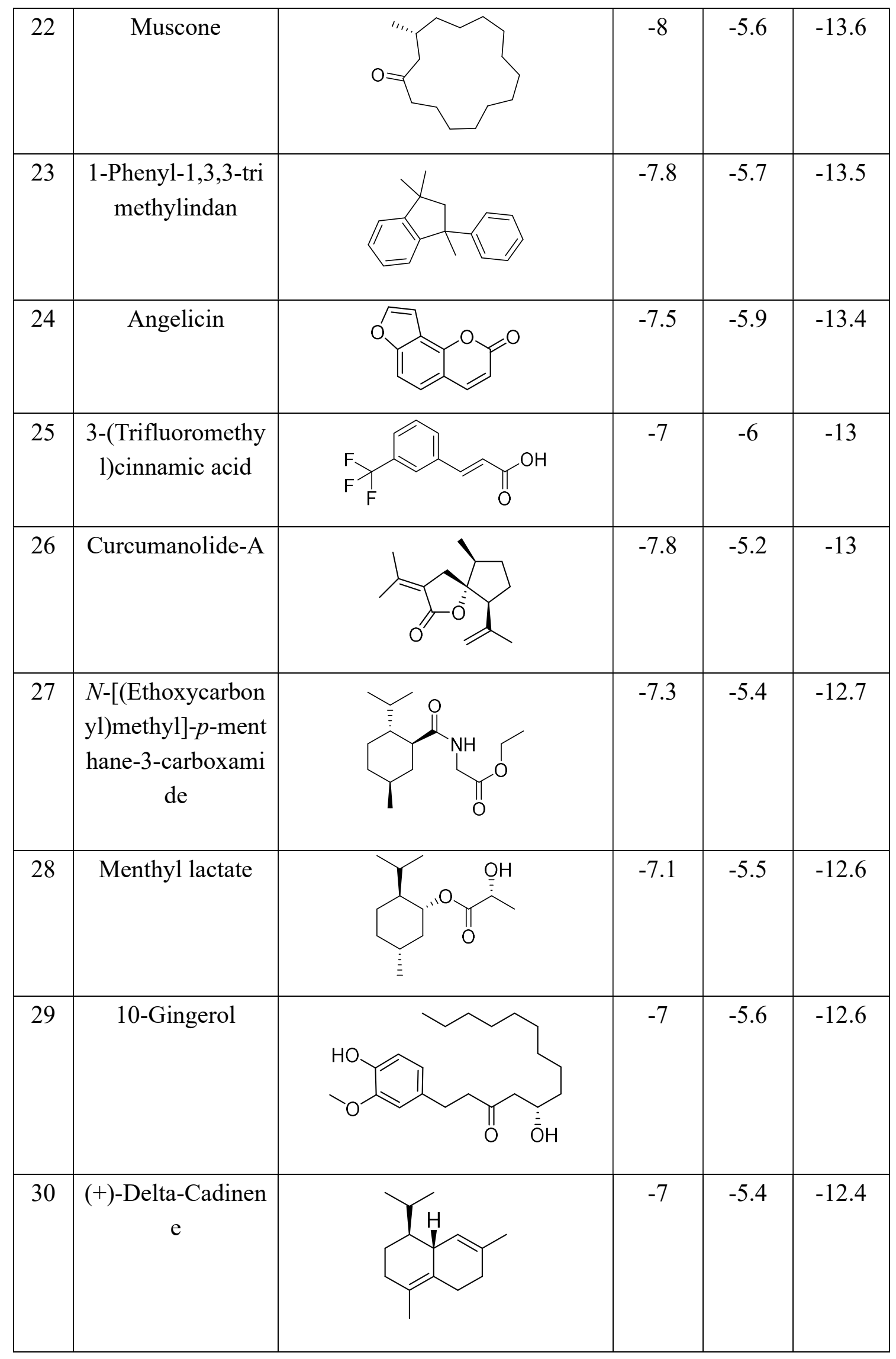




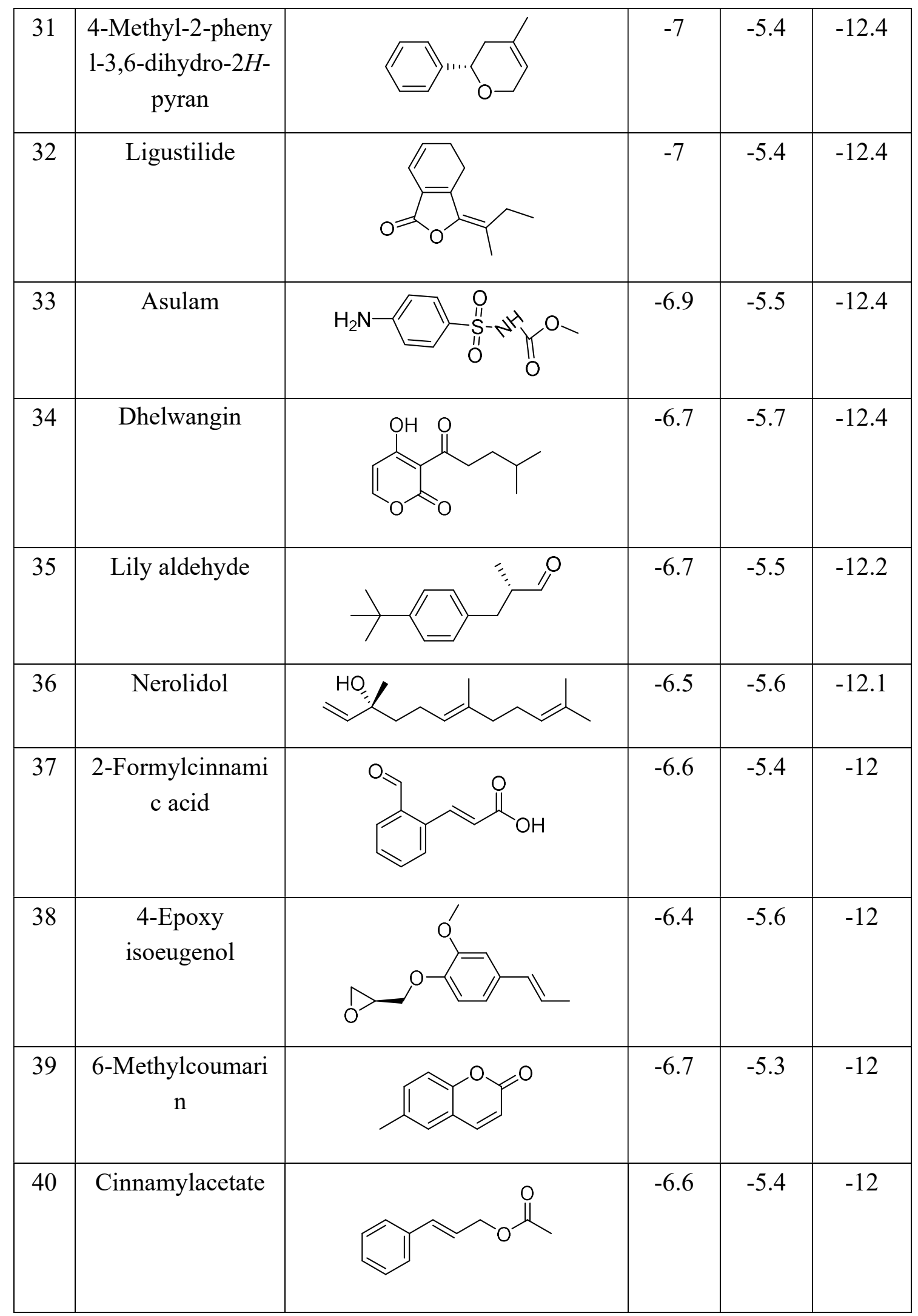




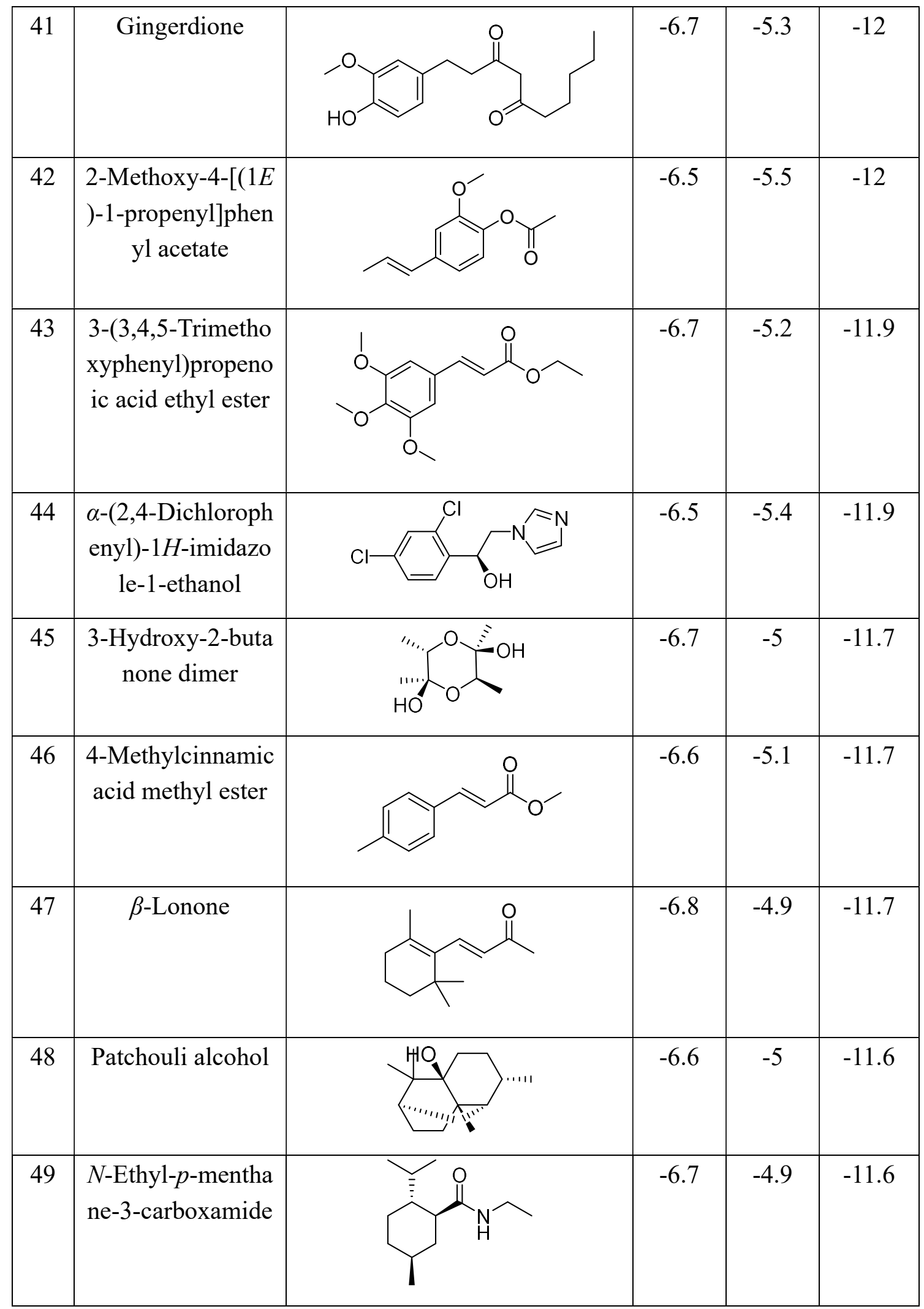




\begin{tabular}{|c|c|c|c|c|c|}
\hline 50 & $(E, E)$-Farnesol & $\mathrm{H}$ & -6.3 & -5.1 & -11.4 \\
\hline 51 & $\alpha$-Ionone & & -6.4 & -5 & -11.4 \\
\hline 52 & $\begin{array}{c}\text { Ethyl } \\
(2 E)-3-(4-h y d r o x \\
\text { yphenyl)acrylate }\end{array}$ & & -6.5 & -4.9 & -11.4 \\
\hline 53 & Isoeugenol & -0 & -6.2 & -5.2 & -11.4 \\
\hline 54 & $\begin{array}{c}\text { Ethyl } \\
\text { 4-chlorocinnamat } \\
\text { e }\end{array}$ & & -6.2 & -5 & -11.2 \\
\hline 55 & Terpineol & & -6.4 & -4.8 & -11.2 \\
\hline 56 & $\begin{array}{l}(E, E, E)-2,6,10-\text { Tri } \\
\text { methyldodeca-2,6 } \\
\text {,9,11-tetraen-1-al }\end{array}$ & & -6.2 & -5 & -11.2 \\
\hline 57 & $\begin{array}{c}\text { 3-Phenylpropioni } \\
\text { c acid }\end{array}$ & & -6.3 & -4.8 & -11.1 \\
\hline 58 & $\begin{array}{l}\text { 2-Benzylidene-1- } \\
\text { heptanol }\end{array}$ & & -6.3 & -4.8 & -11.1 \\
\hline 59 & Azulene & & -6.1 & -4.9 & -11 \\
\hline
\end{tabular}




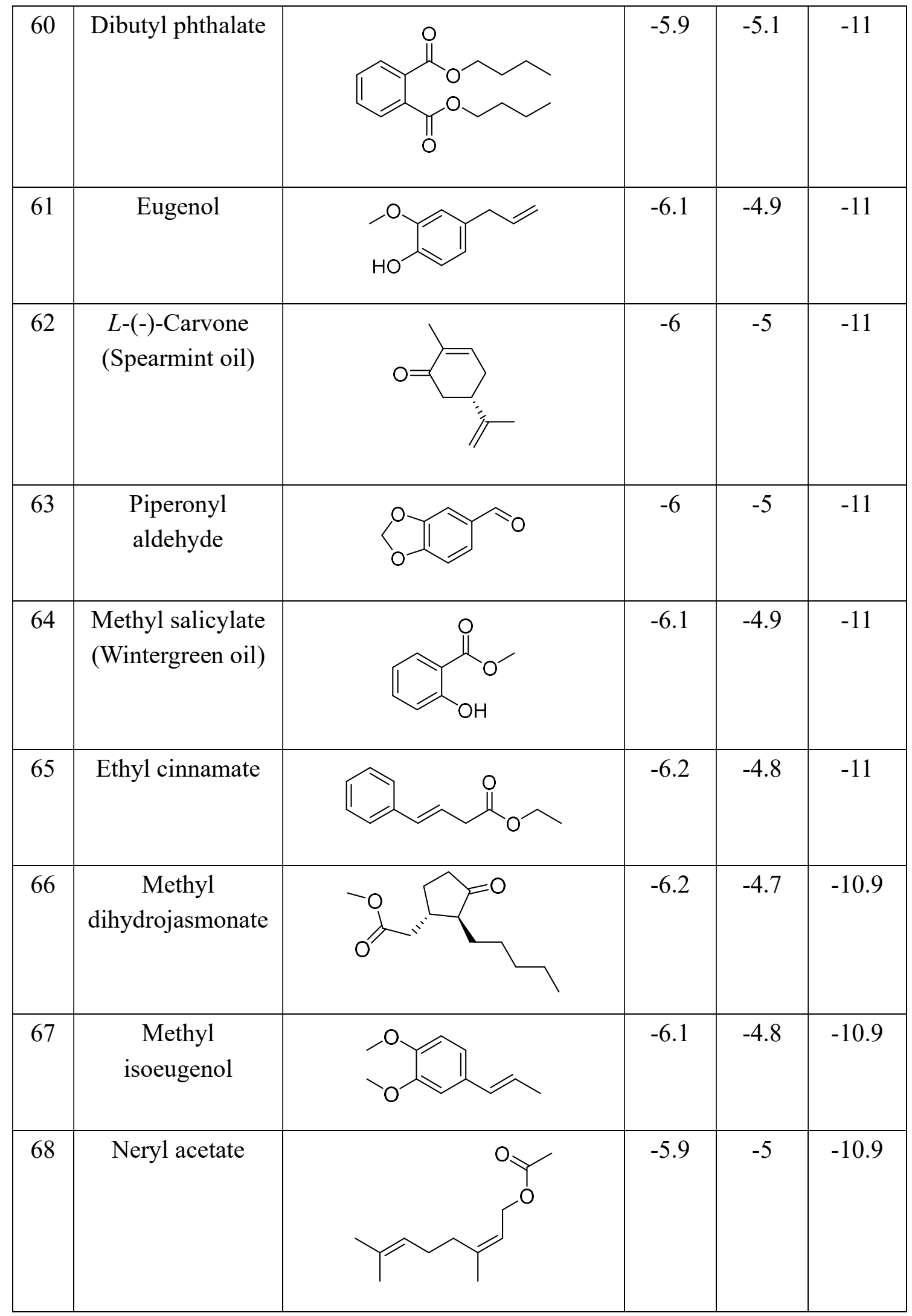




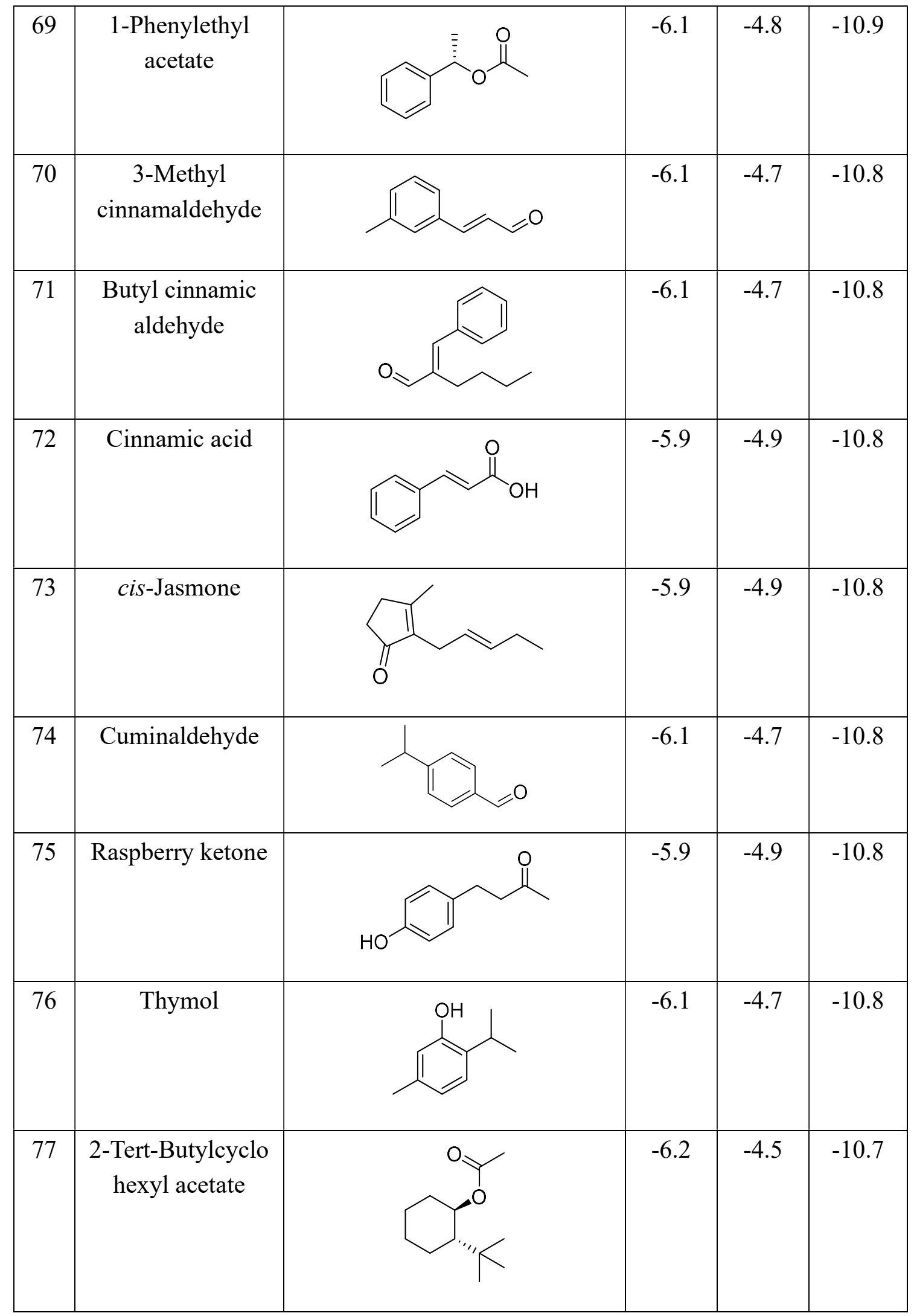









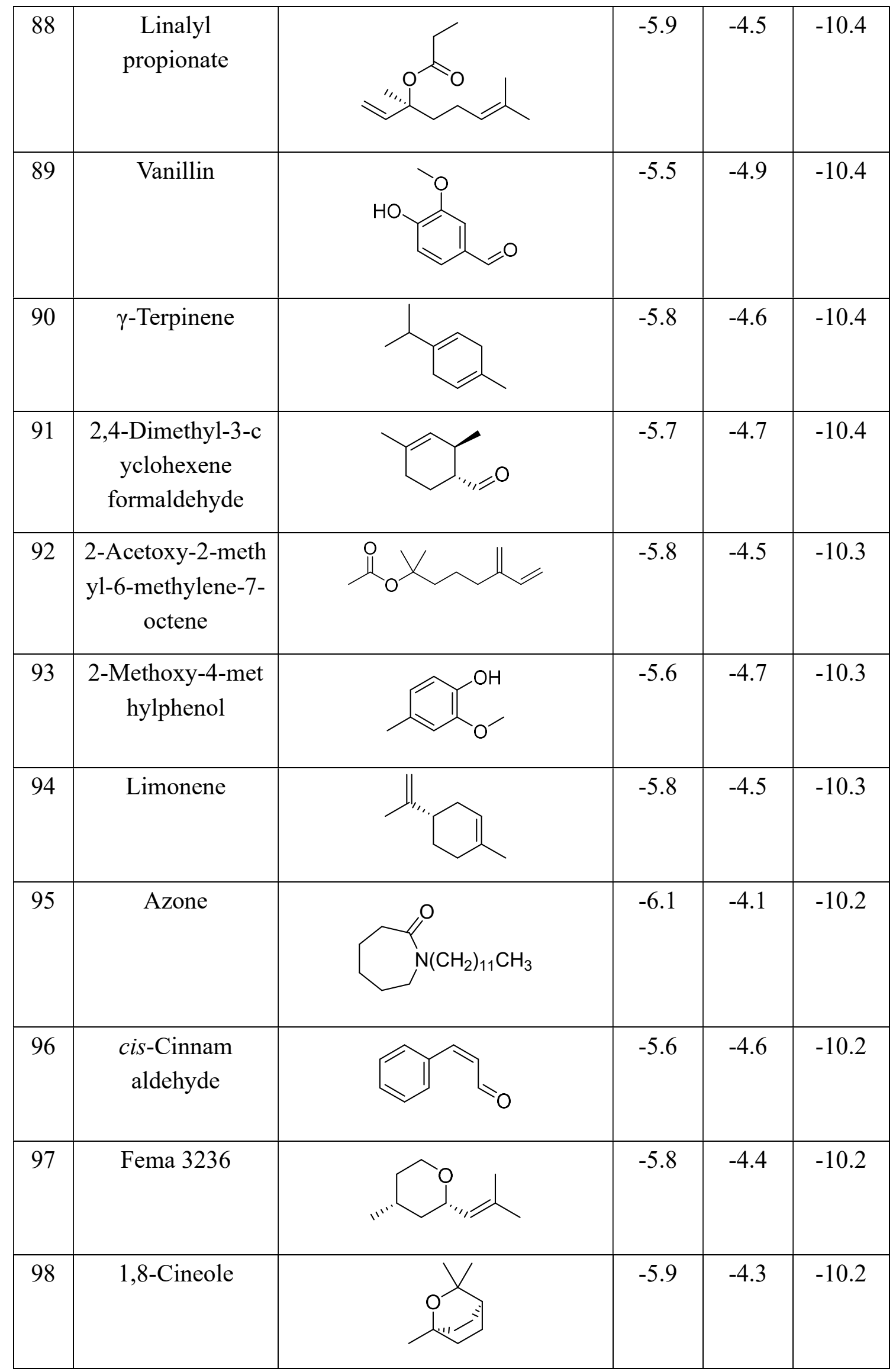




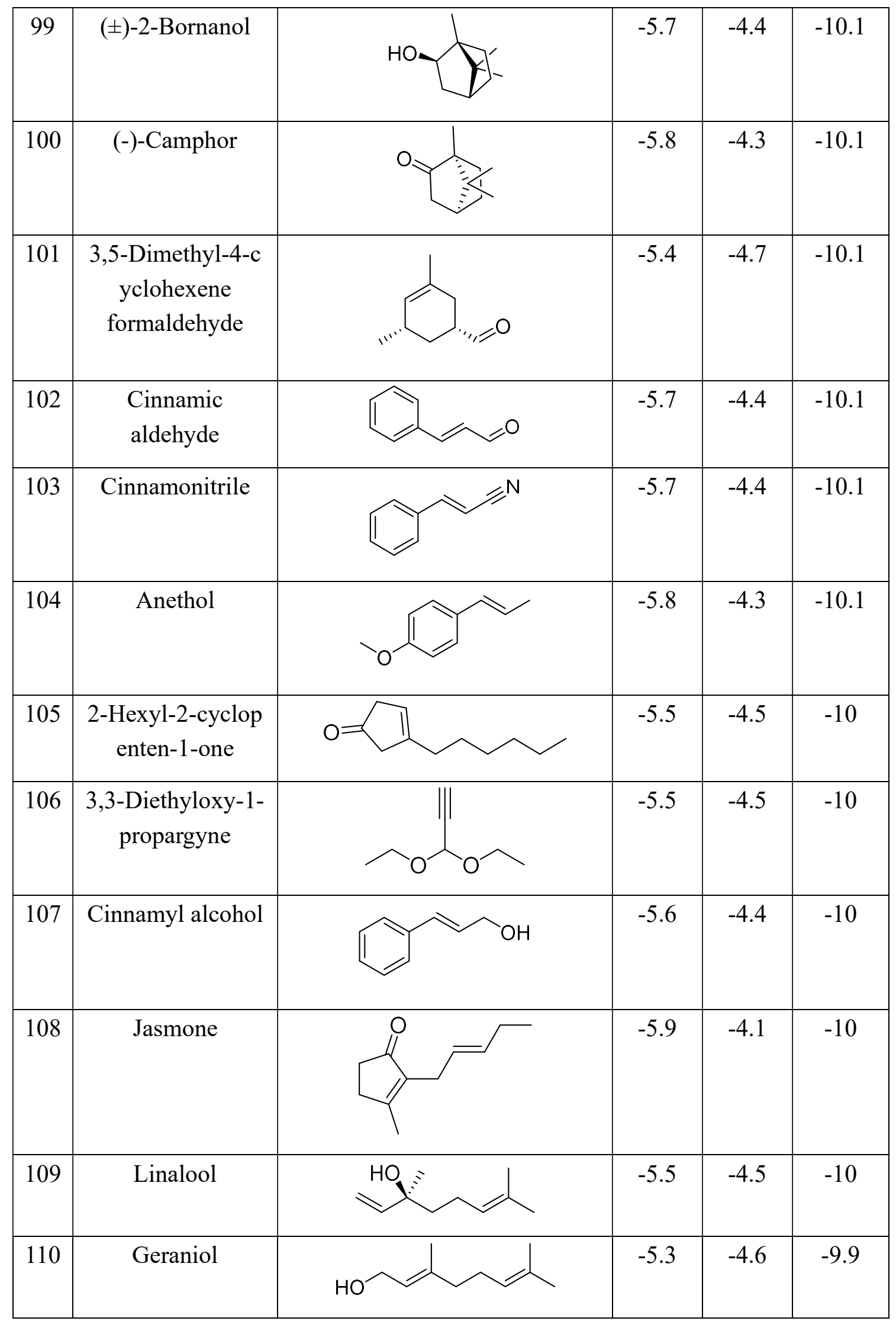




\begin{tabular}{|c|c|c|c|c|c|}
\hline 111 & Nerol & & -5.4 & -4.5 & -9.9 \\
\hline 112 & $\begin{array}{c}(R)-(+)-\beta \text {-Citronel } \\
\text { lol }\end{array}$ & $\mathrm{HO}$ & -5.3 & -4.6 & -9.9 \\
\hline 113 & Citral & & -5.4 & -4.4 & -9.8 \\
\hline 114 & $\begin{array}{c}N, 2,3 \text {-Trimethyl-2 } \\
\text {-isopropylbutamid } \\
\mathrm{e}\end{array}$ & & -5.7 & -4.1 & -9.8 \\
\hline 115 & $\begin{array}{c}\text { Para-Mentha- } 8 \text {-th } \\
\text { iolone }\end{array}$ & & -5.6 & -4.2 & -9.8 \\
\hline 116 & $\gamma$-Decalactone & & -5.3 & -4.5 & -9.8 \\
\hline 117 & Comphene & & -5.5 & -4.2 & -9.7 \\
\hline 118 & $\begin{array}{c}\text { Linoleic acid } \\
\text { (Grape seed oil) }\end{array}$ & & -5.1 & -4.6 & -9.7 \\
\hline 119 & Sabinene & & -5.4 & -4.3 & -9.7 \\
\hline 120 & Anisaldehyde & & -5.3 & -4.3 & -9.6 \\
\hline 121 & Apricolin & & -5.4 & -4.2 & -9.6 \\
\hline 122 & $\begin{array}{c}\text { Phenylethyl } \\
\text { alcohol }\end{array}$ & & -5.3 & -4.3 & -9.6 \\
\hline
\end{tabular}









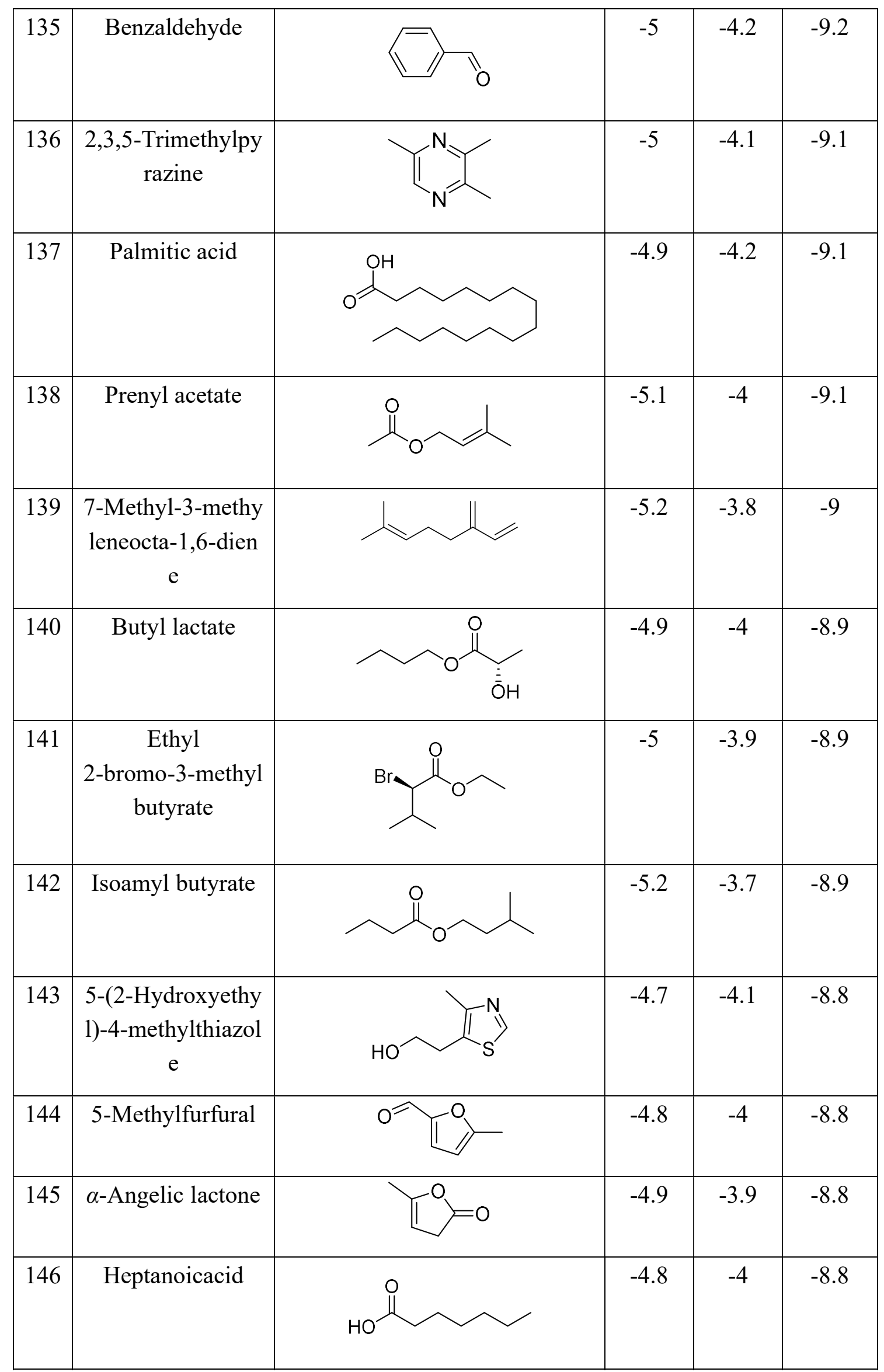




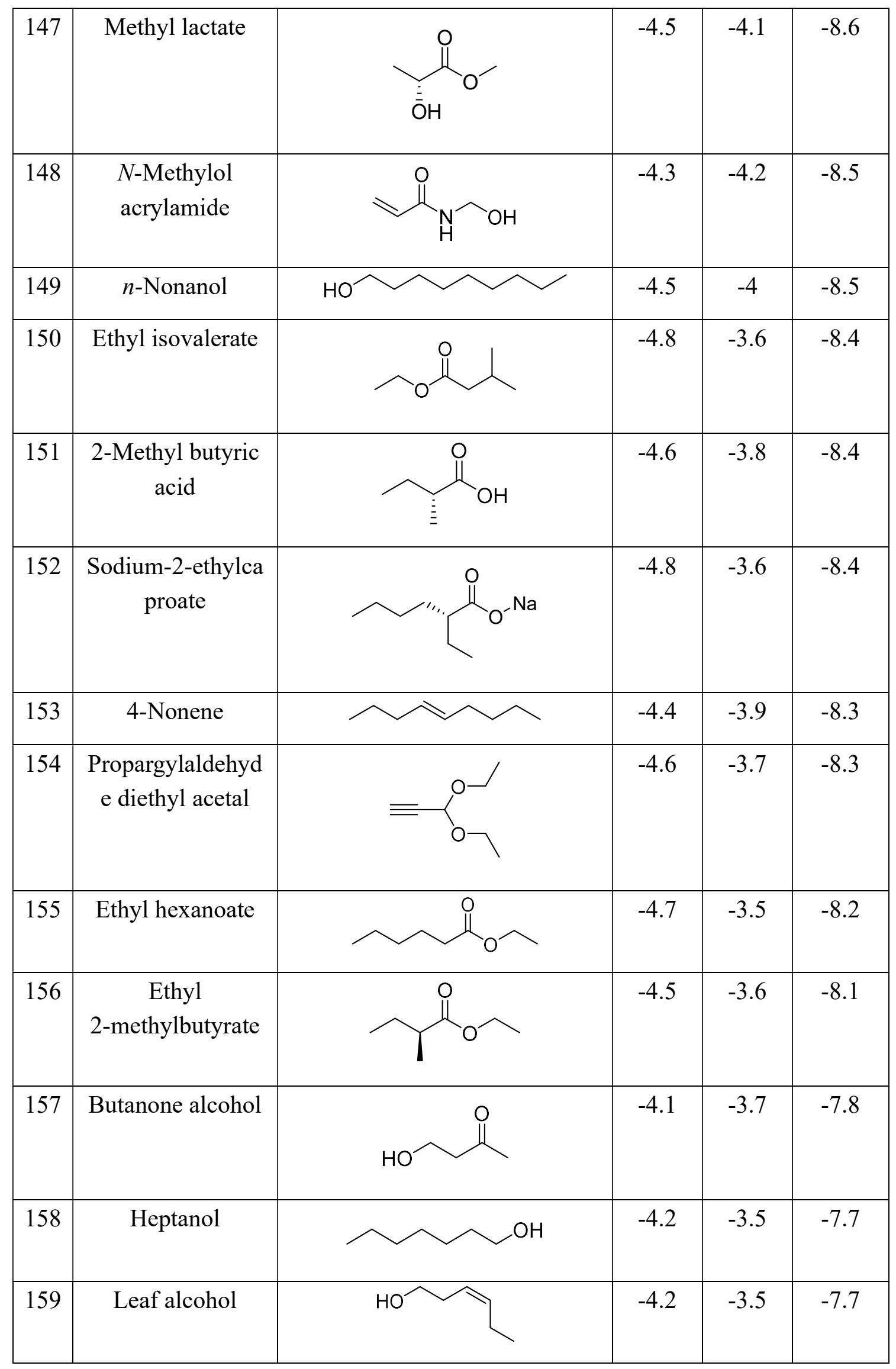




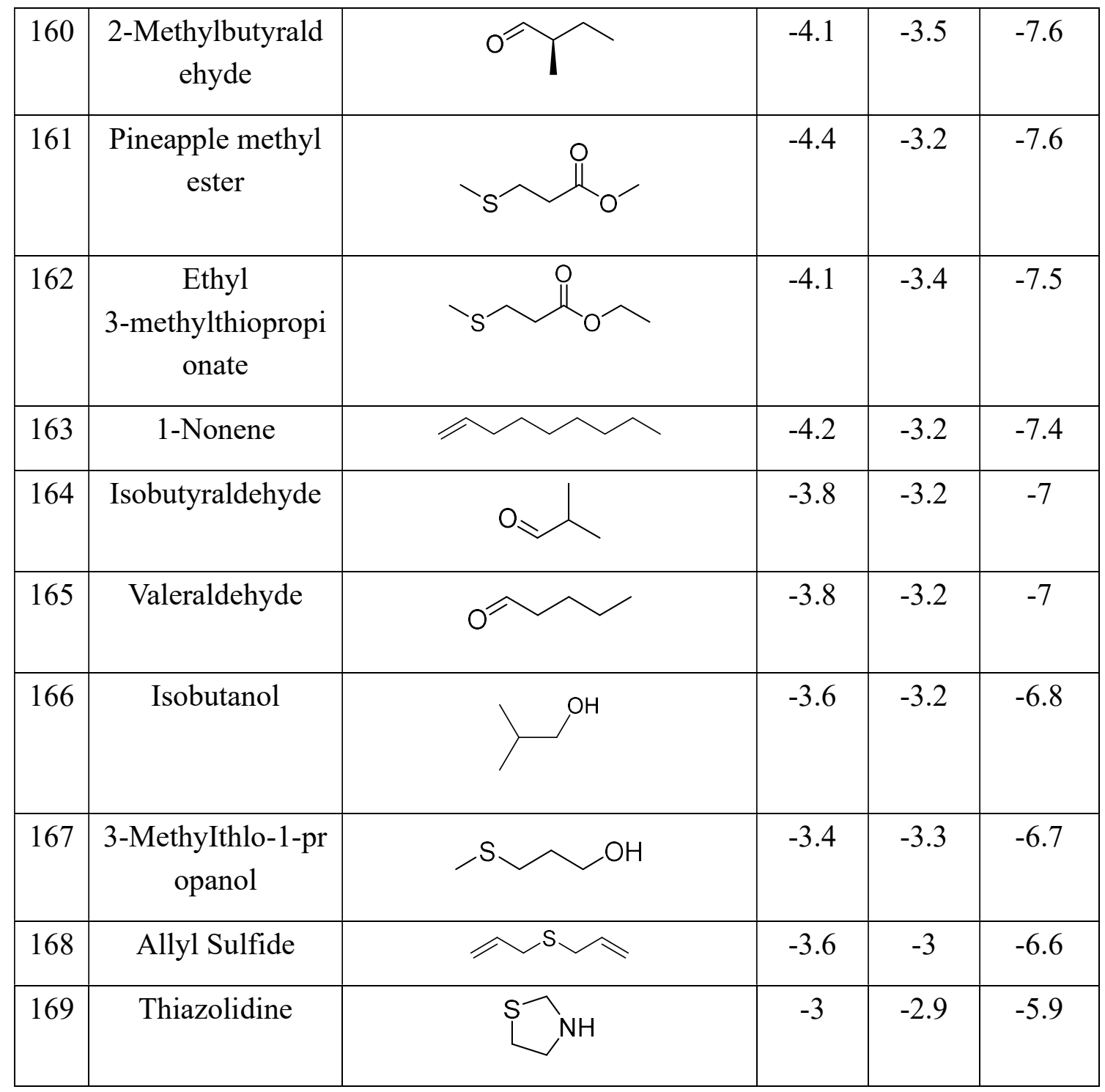

